\title{
FERMENTATION OF KEPOK BANANA PEEL-CORN HOMINY MIXED SUBSTRATE FOR DIETARY INCLUSION IN BROILER RATION
}

\section{Fermentasi Substrat Campuran Kulit Pisang Kepok dan Ampok Jagung dalam Ransum Ayam Pedaging}

\author{
Fadilla Anwar ${ }^{1}$, Catur Sriherwanto ${ }^{2, \star}$, Etyn Yunita ${ }^{1}$, Imam Suja'i $^{2}$ \\ ${ }^{1}$ Dept. Biologi, Fakultas Sains dan Teknologi, Universitas Islam Negeri (UIN) Syarif Hidayatullah Jakarta. \\ ${ }^{2}$ Laboratory for Biotechnology, BPPT, Building 630 PUSPIPTEK Area, Setu, \\ Tangerang Selatan, Banten 15314 \\ *E-mail: catur.sriherwanto@bppt.go.id
}

\begin{abstract}
To reduce broiler production cost, a study was carried out on utilisation of alternative, less costly feed components, namely kepok banana peel and corn hominy which were mixed and fermented using the fungus Rhizopus oryzae. The fermented substrate was added into commercial feed in order to determine its influence on the poultry's production performance. This study employed a completely randomized design (CRD) with four treatments: one using $100 \%$ pure commercial feed, and the other three commercial feed mixed with the fermented feed component at the levels of 5\%,10\% and 15\%. All treatments were repeated four times during 25 days growth period. The results showed that supplementation of the fermented ingredient in the broiler ration at the levels of $5 \%, 10 \%$, or $15 \%$ had no significant effect $(P>0,05)$ on the feed consumption, body weight gain, feed conversion ratio, and the final body weight of the animals. Although mixing the fermented feed ingredient up to $15 \%$ in the commercial feed promoted the growth of the broilers, the growth performance were not yet comparable to pure commercial feed.
\end{abstract}

Keywords: Corn hominy, broiler, fermentation, kepok banana peel, Rhizopus oryzae

\begin{abstract}
ABSTRAK
Untuk mengurangi biaya produksi ayam pedaging, dilakukan pengkajian penggunaan bahan penyusun pakan alternatif yang lebih murah, yaitu kulit pisang kepok dan ampok jagung yang dicampur dan difermentasi menggunakan jamur Rhizopus oryzae. Hasil fermentasi tersebut lalu ditambahkan pada pakan komersial ayam pedaging dengan tujuan mengetahui pengaruhnya terhadap penampilan produksi ayam pedaging. Penelitian ini menggunakan Rancangan Acak Lengkap (RAL) dengan empat perlakuan, yaitu satu perlakuan 100\% pakan komersial murni, dan tiga perlakuan pakan komersial yang dicampur bahan pakan hasil fermentasi tersebut dengan kadar 5\%, 10\%, dan 15\%. Seluruh perlakukan diulang empat kali selama 25 hari masa pemeliharaan. Hasil penelitian menunjukkan bahwa penambahan bahan pakan terfermentasi ke dalam ransum ayam pedaging pada kadar 5\%, 10\%, atau $15 \%$ tidak memberikan pengaruh nyata $(P>0,05)$ terhadap konsumsi pakan, pertambahan bobot badan, nilai koversi pakan, dan bobot badan akhir hewan. Meskipun penambahan bahan pakan fermentasi tersebut hingga 15\% dalam pakan komersial mendukung pertumbuhan ayam pedaging, namun capaian pertumbuhannya belumlah sebaik pakan komersial.
\end{abstract}

Kata kunci: Ampok jagung, ayam pedaging, fermentasi, kulit pisang kepok, Rhizopus oryzae 


\section{INTRODUCTION}

Poultry production requires up to $70 \%$ of the total production cost to be spent in feeds (Goodarzi Boroojeni et al. 2016). Thus, reducing the production cost, hence increasing profit margin, can be done by utilising alternative feed ingredients derived from agroindustrial wastes and byproducts, as well as abundantly available local resources (Ditjennakkeswan 2014). Such potential feed components that have been experimented for use in broiler diets include sago pith (Ab Jalil et al. 2014), palm kernel cake (Alshelmani et al. 2016), orange and banana peel (Siyal et al. 2016), cassava (Boonsinchai et al. 2016; Nsa et al. 2016), olive cake (Al-Harthi 2016), rice milling waste (Yusuf et al. 2015), mushroom waste (Camay 2016), brewer dried grains (Okpanachi et al. 2014), apple peel (Heidarisafar et al. 2016), ginger waste meal (Pati et al. 2015), corn husk waste (Ningrumsari and Budiasih 2015), sunflower meal (Alagawany et al. 2015), grape byproduct (Brenes et al. 2016), and guava fruit meal (Bikrisima et al. 2016).

There are, however, some problems associated with feed ingredients derived from agroindustrial origin. The relatively high content of antinurients such as lectins, polyphenolic compounds, toxic amino acids, saponins, cyanogenic glycosides, protease inhibitors, and oxalates (Martens et al. 2012) limit the inclusion rate of the feed components in the poultry diet (Schedle 2016). Efforts to reduce the antinutrional factors, thus increasing the digestibility and nutrient availability, have been undertaken using a number of techniques including treatments using heat, chemicals, machineries, enzyme supplementation, as well as fermentation (Pasaribu 2007; Martens et al. 2012; Ravindran 2013; Schedle 2016).

Solid fermentation, owing to being simple and low cost, has been employed in various studies to develop potential poultry feed components of plant origin. As the fermenting agent, the edible fungi Rhizopus spp. have been used on such substrates as sago pith (Ab Jalil et al. 2014), banana peel (Martaguri 2010; Koni 2013), cassava bagasse (Purnomo et al. 2015), Jatropha curcas meal (Sumiati et al. 2011; Yusriani et al. 2011) and soybean meal (Qudri 2001).
In this study, solid fermentation of mixed substrate comprising Kepok banana peel and corn hominy using Rhizopus oryzae (Biotech Laboratory Culture Collection) was carried out to prepare an alternative feed ingredient. Once prepared, this fermented feed component was subsequently mixed at different inclusion levels with commercial poultry basal diet. Subsequent feeding experiment was carried out with the aim of investigating its effect on broiler growth performance.

\section{MATERIALS AND METHODS}

\section{Feed fermentation}

Fermentation was carried out at the Feed Biotechnology Laboratory-BPPT, Serpong, Banten and feed test on broiler chickens in Pabuaran, Gunung Sindur, Bogor, West Java. Fermentation substrates consisted of kepok banana peel (BP) and corn hominty $(\mathrm{CH})$. BP was diced into smal size, homogenised using a blender to produce a brown mash texture. This BP mash was mixed with $\mathrm{CH}$ at the weigt ratio of $4: 1$, sterilised at $121^{\circ} \mathrm{C}$ for 15 minutes. Having cooled to room temperature, the substrates were mixed with starter powder of $R$. oryzae (3.3 $\times$ $10^{7} \mathrm{cfu} / \mathrm{g}$ ) at the concentration of $1-1.5 \mathrm{~g} / 100$ $\mathrm{g}$ substrate, and moisturised to $70 \%$ using a mineral solution consisting of (per $1000 \mathrm{~mL}$ solution): $2.7 \mathrm{~g} \mathrm{KH}_{2} \mathrm{PO}_{4}, 8.0 \mathrm{~g}\left(\mathrm{NH}_{4}\right)_{2} \mathrm{SO}_{4}$, and $13.4 \mathrm{~g}$ urea. Incubation was then carried out at $28-30^{\circ} \mathrm{C}$ or at room temperature for 24-48 hours.

Once the fermentation was successsful, indicated by the substrate physically being transformed into cottony white cake with soft cheesy texture, the fermented substrate was sliced into small cubes, approximately $1 \mathrm{~cm}^{3}$, and dried at $60^{\circ} \mathrm{C}$ for 24 hours. The dried fermented feeds were subjected to proximate analyses.

\section{Feed treatment}

Four feeds were prepared by mixing the basal diet of BR 11 (Charoen Pokphand Ltd.) commercial poultry feed with the fermented feed at different inclusion levels of $0,5,10$, and $15 \%$, respectively. The two feed components were firstly homogenized separately, mixed, and then made into crumble forms in Indo Feed animal feed factory, Bogor, West Java). 


\section{Birds and housing}

Ninty six one day old (broiler) chickens (DOC) (Kerta Mulya Sejahtera Ltd, Sukabumi, West Java) were randomly allotted to 16 squarely-fenced pens, six birds per pen (1 $\mathrm{m}^{2} /$ pen). The pens were located inside a closed-sided, above-ground house insulated by bamboo wood with gaps which allowed natural ventilation, and bedded with rice husks. In each pen, a drinker and a plastic feeder were equipped to provide water and feed ad libitum.

\section{Feeding test}

Feeding test on the chickens was undertaken in a completely randomized design with four replications per treatments, and a 25-day rearing period. Four feeding treatments were carried out using four different types of ration as mentioned previously. Parameter measured included feed consumption, body weight gain, and feed conversion ratio (FCR). Data obtained were processed using Statistical Package for the Social Science (SPSS) 20.

\section{RESULTS AND DISCUSSION}

Supplementing the fermented feed into the commercial basal diet up to $15 \%$ inclusion level lowered the protein content to less than $14.5 \%$ from the initial value of $15 \%$. The crude fibre content, however, increased for those feeds containing 10 and $15 \%$ fermented feed. Interestingly, the treatment feed added with the $5 \%$ fermented feed contained less fibre content than the pure $100 \%$ commercial feed. This impossible result could be due to experimental error, since the banana peel contain about 21$50 \%$ crude fibre (Agustono et al. 2011; Yosephine et al. 2012). Addition of the peel should have made the crude fibre content higher than the initial value of $7.25 \%$.

Both basal diet and treated diets in this study did not meet the standard requirement of crude protein content of at least $19.0 \%$ for broiler starter (Badan Standar Nasional 2006a) and minimum $18.0 \%$ for broiler finisher diets (Badan Standar Nasional 2006b), as well as crude fibre content of maximum $6.0 \%$ (Badan Standar Nasional 2006a; Badan Standar Nasional 2006b). This protein content was also much lower than those reported in other similar studies involving banana peels in broiler diets, in which the values ranged from 20.16 to 23.08\% (Martaguri 2010; Koni et al. 2013; Koni 2013; Siahaan et al. 2014; Sunu et al. 2014;

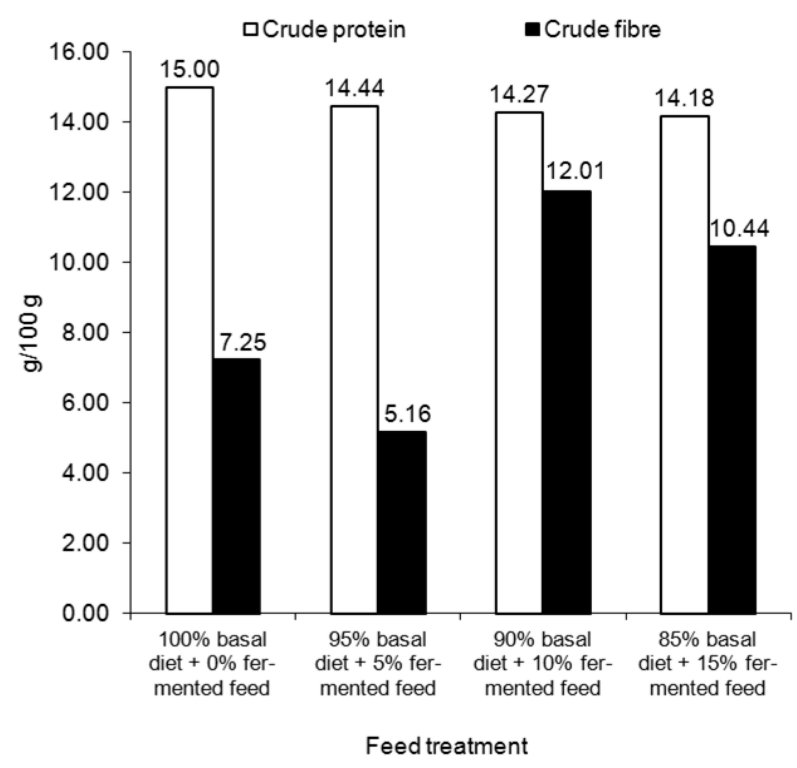

Figure 1. Crude protein and fibre content of the broiler feed made from commercial-feed basal diet (BD) combined with the fermented feed (FF) at different proportion

Zahra et al. 2014; Hudiansyah et al. 2015). In two of these studies (Sunu et al. 2014; Zahra et al. 2014), the crude fibre content was exceeding the recommended maximum values of $6.0 \%$ as well.

The presence of the fermented feed component in the broiler ration brought no advantage over fermented feed-free ration in terms of feed intake (Figure 2) and growth profiles (Figure 3) during the 25-day rearing period. Both average feed consumption and average body weight were always higher for the broilers fed with $100 \%$ commercial feed than those fed with fermented-feed added diets. This was likely due to the lower protein content of the latter. Inadequate amount of protein would negatively impact bird growth as, apart of being main component of the biologically active molecules in the body, it plays important roles in the body tissue synthesis and renovation (Beski et al. 2015).

Further data analysis at the end of rearing period ( $25^{\text {th }}$ day) on the average final feed consumption ratio, average final body weight gain, FCR, and average final body weight (Table 1) confirmed the superiority of $100 \%$ commercial basal diet compared to all the other treated feeds. Statistic analysis, however, gave no significant difference ( $P>0.05)$ across all the average final weight and FCR values as a result of fermented feed treatment. Amongst all the feeds added with the fermented ingredient, combination of $90 \%$ commercial basal diet plus 10\% fermented feed gave the best results, indicated by the values of average final body weight gain, 
Table 1. Growth performance of broiler chicken for 25 days rearing period

\begin{tabular}{lcccc}
\hline Feed treatment & $\begin{array}{c}\text { Average final } \\
\text { feed consumption } \\
(\mathrm{g})\end{array}$ & $\begin{array}{c}\text { Average final } \\
\text { body weight gain } \\
(\mathrm{g})\end{array}$ & $\begin{array}{c}\text { Feed } \\
\text { conversion } \\
\text { ratio (FCR) }\end{array}$ & $\begin{array}{c}\text { Average final } \\
\text { body weight } \\
(\mathrm{g})\end{array}$ \\
\hline $100 \%$ basal diet $+0 \%$ fermented feed & $1673.7 \pm 12.8$ & $1041.3 \pm 76.7$ & $1.53 \pm 0.93$ & $1097.6 \pm 76.1$ \\
$95 \%$ basal diet $+5 \%$ fermented feed & $1576.7 \pm 42.4$ & $901.5 \pm 65.7$ & $1.65 \pm 0.80$ & $956.2 \pm 64.6$ \\
$90 \%$ basal diet $+10 \%$ fermented feed & $1591.3 \pm 82.5$ & $950.0 \pm 113.1$ & $1.59 \pm 0.10$ & $1005.0 \pm 113.4$ \\
$85 \%$ basal diet $+15 \%$ fermented feed & $1621.2 \pm 106.9$ & $881.6 \pm 57.0$ & $1.74 \pm 0.19$ & $935.6 \pm 57.6$ \\
\hline
\end{tabular}

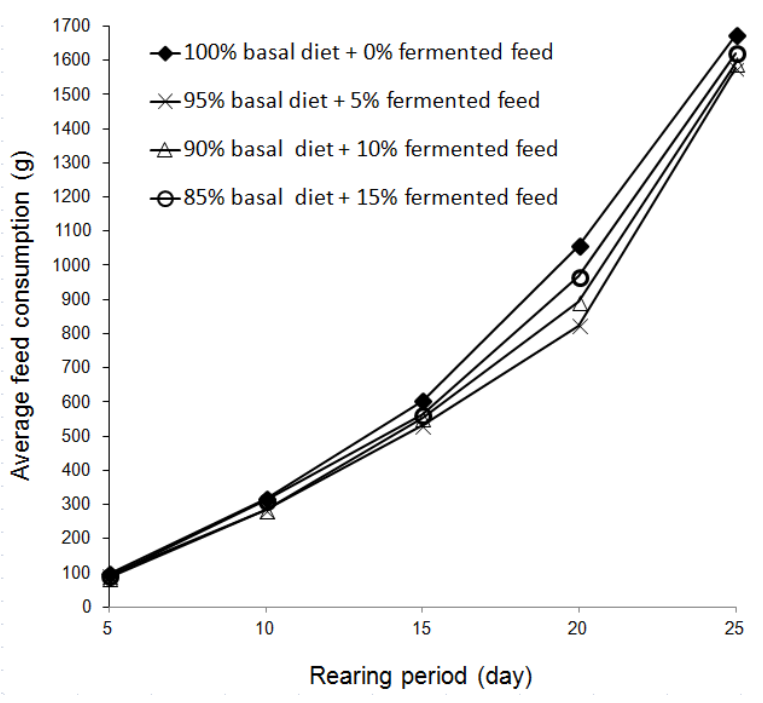

Figure 2. The effect of fermented feed inclusion level on the feed consumption of broilers

FCR, and average final body weight.

Based on the obtained data (Table 1), the feed consumption rates were $66.9,63.1$, 63.7, and 64.8 g.day $^{-1}$ per bird as the fermented feed was added at the levels of 0,5 , 10 and $15 \%$, respectively. Such negative influence on daily average feed consumption was also reported in other similar studies using Rhizopus-fermented banana peels (Martaguri 2010; Koni 2013). The much more adverse effect of Rhizopus-fermented feed stuff was demonstrated when Jatropha curcas was used as the substrate, where $9 \%$ inclusion of the fermented feed in the ration caused the overall feed consumption during grower-finisher period decreased to less than 20\% (Sumiati et al. 2011).

The lower consumption rate explained why the values of FCR in basal diet fed broilers (1.53) were much better compared to those fed with fermented feed-added rations (1.59-1.74). These results are compa-

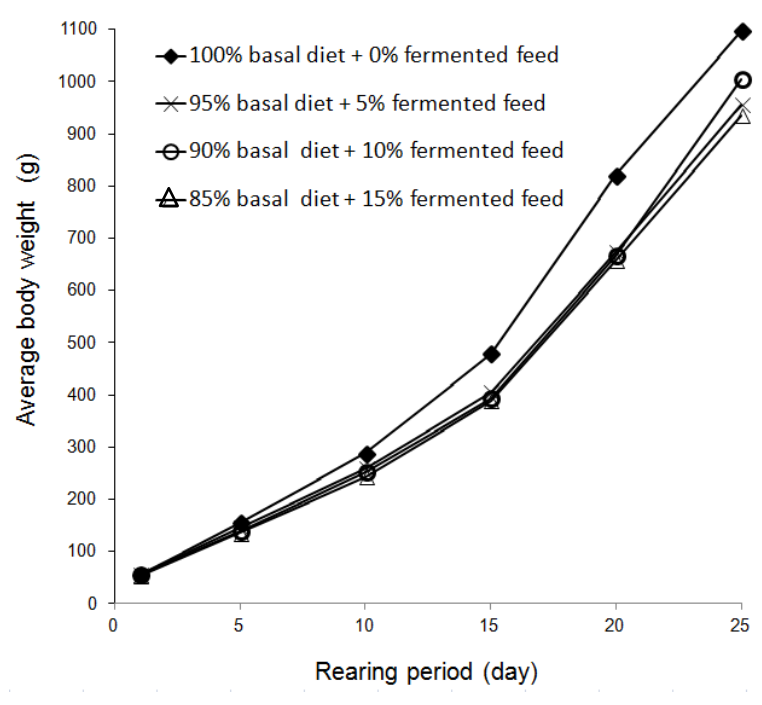

Figure 3. The effect of fermented feed inclusion level on the growth profile of broilers

rable with similar works previously reported (Martaguri 2010), despite the fact that equiprotein principle was considered during formulation of the diets. Hence, the discrepancy was most probably caused by the protein quality (adequate and balanced amino acid composition) and the presence of antinutrient components in the diets (Beski et al. 2015).

\section{CONCLUSION}

Inclusion of $R$. oryzae fermented feed ingredient based on the mixed substrate consisting of kepok banana peels and corn hominy reduced the crude protein content of basal diet. Although promoting broiler growth, supplementing 5,10 , and $15 \%$ of the fermented feed in the diets had no advantage to the birds in term of the feed consumption, growth performance, and productivity. 


\section{REFERENCES}

Ab Jalil $A$, Abdullah $N$, Alimon AR, Abd-Aziz $S$ (2014) Nutrient enhancement of ground sago (Metroxylon sagu Rottboll) pith by solid state fermentation with Rhizopus oligosporus for poultry feed. J Food Res 4:1-15. doi: 10.5539/jfr.v4n2p1

Agustono, Herviana W, Nurhajati T (2011) Kandungan protein kasar dan serat kasar kulit pisang kepok (Musa paradisiaca yang difermentasi dengan Trichoderma viride sebagai bahan pakan alternatif pada formulasi pakan ikan mas (Cyprinus carpio). J Kelaut 4:53-59

Al-Harthi MA (2016) The efficacy of using olive cake as a by-product in broiler feeding with or without yeast. Ital $\mathrm{J}$ Anim Sci 1-9. doi: 10.1080/1828051X. 2016.1194173

Alagawany M, Farag MR, Abd El-Hack ME, Dhama K (2015) The practical application of sunflower meal in poultry nutrition. Adv Anim Vet Sci 3:634-648

Alshelmani MI, Loh TC, Foo HL, Sazili AQ, Lau WH (2016) Effect of feeding different levels of palm kernel cake fermented by Paenibacillus polymyxa ATCC 842 on broiler growth performance, blood biochemistry, carcass characteristics, and meat quality. Anim Prod Sci 216:216-224

Badan Standar Nasional (2006a) Pakan anak ayam ras pedaging masa awal (broiler starter) SNI 01-3930-2006. Jakarta, Indonesia

Badan Standar Nasional (2006b) Pakan anak ayam ras pedaging masa akhir (broiler finisher) SNI 01-3931-2006. Jakarta, Indonesia

Beski SSM, Swick RA, lji PA (2015) Specialised protein products in broiler chicken nutrition: A review. Anim Nutr 1:47-53. doi: 10.1016/j.aninu.2015.05. 005

Bikrisima SHL, Mahfudz LD, Suthama N (2016) Production capacity of broiler chickens given dietary red guava fruit meal as source of natural antioxidant. J Ilmu dan Teknol Peternak 3:60-75

Boonsinchai N, Potchanakorn M, Kijparkorn $S$ (2016) Effects of protein reduction and substitution of cassava for corn in broiler diets on growth performance, ileal protein digestibility and nitrogen excretion in feces. Anim Feed Sci Technol 216:185-196. doi: 10.1016/j. anifeedsci.2016.03.022

Brenes A, Viveros A, Chamorro S, Arija I (2016) Use of polyphenol-rich grape by-products in monogastric nutrition. A review. Anim Feed Sci Technol 211:117. doi: 10.1016/j.anifeedsci.2015. 09.016

Camay RM (2016) Mushroom (Pleurotus ostreatus) waste powder: its influence on the growth and meat quality of broiler chickens (Gallus gallus domesticus). World J Agric Res 4:98108. doi: 10.12691/wjar-4-4-1

Ditjennakkeswan (2014) Pedoman pelaksanaan pengembangan integrasi ternak unggas TA. 2014. Direktorat Jenderal Peternakan dan Kesehatan Hewan, Kementerian Pertanian, Republik Indonesia, Jakarta

Goodarzi Boroojeni F, Svihus B, von Reichenbach HG, Zentek J (2016) The effects of hydrothermal processing on feed hygiene, nutrient availability, intestinal microbiota and morphology in poultry - a review. Anim Feed Sci Technol. doi: 10.1016/j.anifeedsci. 2016.07.010

Heidarisafar Z, Sadeghi G, Karimi A, Azizi O (2016) Apple peel waste as a natural antioxidant for heat-stressed broiler chickens. Trop Anim Health Prod 48:831-835. doi: 10.1007/s11250-0161001-1

Hudiansyah P, Sunarti D, Sukamto B (2015) Pengaruh penggunaan kulit pisang terfermentasi dalam ransum terhadap ketersediaan energi ayam broiler. Agromedia 33:1-9

Koni TN, Bale-therik J, Kale PR (2013) Pemanfaatan kulit pisang hasil fermentasi Rhyzopus oligosporus dalam ransum terhadap pertumbuhan ayam pedaging. J Vet Sept 14:365370.

Koni TNI (2013) Pengaruh pemanfaatan kulit pisang yang difermentasi terhadap karkas broiler. J IImu Ternak dan Vet 18:153-157

Martaguri I (2010) Respon ayam broiler terhadap kulit pisang batu (Musa brachyarpa) fermentasi dalam ransum 
yang mengandung probiotik Starbio. J Peternak 7:8287

Martens SD, Tiemann TT, Bindelle J, Peters M, Lascano CE (2012) Alternative plant protein sources for pigs and chickens in the tropics - Nutritional value and constraints: $A$ review. J Agric Rural Dev Trop Subtrop 113:101-123

Ningrumsari I, Budiasih R (2015) Optimization of broiler feed production from corn husk waste by Aspergillus niger, Trichoderma viride and its consortium. Pakistan J Nutr 14:300-303

Nsa E, Wogar G, Akpan I (2016) Comparative evaluation of composite cassava root meal, palm oil and crayfish waste mixture as substitute for maize in broiler chicken diet. Am J Exp Agric 11:1-7. doi: 10.9734/AJEA/2016/ 22340

Okpanachi U, Musa AA, Adewoye AT, Adejoh OC (2014) Effects of replacing maize with graded levels of cassava tuber meal, brewer's dried grain and palm oil mixture on the serum biochemistry and carcass characteristics of broiler chickens. IOSR J Agric Vet Sci 7:27-31

Pasaribu T (2007) Produk fermentasi limbah pertanian sebagai bahan pakan unggas di Indonesia. Wartazoa 17:109-116

Pati P, Das SK, Mishra PK, Behura NC, Mishra A, Mandal KD (2015) Effect of inclusion of ginger (Zingiber officinale) waste meal in the diet on broiler performance. Indian $\mathrm{J}$ Anim Nutr 32:305-309

Purnomo D, Isroli, Sugiharto (2015) Total leukosit dan diferensial leukosit darah ayam broiler akibat penggunaan tepung onggok fermentasi Rhizopus oryzae pada ransum. J Ilmu-IImu Peternak 25:59-68

Qudri A (2001) Penggunaan hasil fermentasi bungkil kedelai dalam ransum terhadap pertumbuhan ayam pedaging. J Agripet 2:26-31

Ravindran V (2013) Feed enzymes: The science, practice, and metabolic realities. J Appl Poult Res 22:628-636. doi: 10.3382/japr.2013-00739

Schedle K (2016) Sustainable pig and poultry nutrition by improvement of nutrient utilisation - A review. Die Bodenkultur J L Manag Food Environ 67:45-60. doi: 10.1515/boku-20160005

Siahaan NB, Sunarti D, Yunianto VD (2014) Pengaruh penggunaan kulit pisang biokonversi dalam ransum terhadap penyerapan kalsium serta kekuatan tulang ayam broiler. J IImu-IImu Peternak 24:18-23

Siyal FA, Wagan R, Bhutto ZA, Tareen $\mathrm{MH}$, Arain MA, Saeed M, Brohi SA, Soomro RN (2016) Effect of orange and banana peels on the growth performance of broilers. Adv Anim Vet Sci 4:376-380. doi: 10.1002/da. 20054

Sumiati S, Farhanuddin F, Hermana W, Sudarman A, Istichomah N, Setiyono A (2011) Performa ayam broiler yang diberi ransum mengandung bungkil biji jarak pagar (Jatropha curcas L.) hasil fermentasi menggunakan Rhizopus oligosporus. Media Peternak 34:117125. doi: 10.5398/medpet.2011.34. 2.117

Sunu P, Sukamto B, Suprijatna E (2014) Penggunaan sorgum dan kulit pisang yang terolah secara kimiawi terhadap kecernaan nutrien pada ayam broiler. Agromedia 32:25-36

Yosephine A, Gala V, Ayucitra A, Retnoningtyas ES (2012) Dalam pembuatan kertas serat campuran. 11:94-100

Yusriani Y, Toharmat T, Sumiati, Wina E, Setiyono A (2011) Kombinasi perlakuan penggunaan bungkil biji jarak pagar terfermentasi dan penambahan enzim terhadap energi termetabolis, retensi $\mathrm{N}, \mathrm{P}, \mathrm{Ca}$ dan serat kasar tercerna. J IImu Ternak dan Vet 16:163-172

Yusuf M, Lawan AA, Antyev M, Faruk A, Doma UD, Bello KM, Adamu N, Muhammed F (2015) Response of broiler chickens to dietary levels of rice milling waste. ATBU J Sci Technol Educ 3:134-142. doi: 10.1017/ CBO9781107415324.004

Zahra AA, Supriyatna E, Sukamto B (2014) Pengaruh pemberian pakan sorgum dan kulit pisang terhidrolisis dengan $\mathrm{NaOH}$ terhadap lemak dan kolesterol ayam broiler. Agromedia 32:74-80 